\title{
Malino: Kota Perdamaian dan Kawasan Wisata di Gowa 1946-2002
}

\author{
M. Rijal, Mustari Bosra dan M. Rasyid Ridha \\ Pendidikan Sejarah FIS UNM \\ muhammadrijal074@gmail.com
}

\begin{abstract}
Abstrak
Penelitian ini bertujuan untuk mengetahui gambaran umum Malino sebagai tempat konferensi dan tempat wisata yang di mulai dari tahun 1946 hingga tahun 2002, serta serta menjelaskan latar belakang diadakannya konferensi Malino di Kecamatan Tinggimoncong. Penelitian ini menggunakan dengan menggunakan metode penelitian sejarah yang terdiri dari empat tahapan, yaitu heuristik (mencari dan mengumpulkan sumber), kritik sumber (kritik intern dan ektern), interpretasi (penafsiran sumber) dan historiografi (penulisan sejarah). Metode pengumpulan data dilakukan dengan cara melakukan penelitian lapangan terdiri dari wawancara dan mengumpulkan sumbr arsip serta literatur-literatur yang berhubungan. Penelitian ini merupakan penelitian sejarah dengan pendekatan deskriptif kualitatif, sehingga dalam proses penelitiannya menggunakan metode penelitian yang sesuai dengan kaidah keilmuan sejarah yang terdiri atas beberapa tahapan. Tahapan tersebut adalah heuristik, kritik, interpretasi, dan historiografi. Hasil penelitian ini menunjukkan bahwa Malino sebagai tempat konferensi dan tempat wisata, ditahun 1946 adalah awal mula Malino dijadikan sebagai tempat berlangsungnya konferensi pembentukan NIT oleh kolonial Belanda, kemudian di zaman reformasi antara tahun 2001 sampai 2002 setidaknya ada dua kegiatan penting yakni perundingan damai konflik Poso dan konflik Maluku yang juga diadakan di Malino yang dimana perundingan tersebut mencapai kesepakatan damai diantara pihak yang bertikai. Selain Malino sebagai tempat perdamaian juga sebagai daerah wisata dimana sejak tahun 1975 Malino dijadikan sebagai daerah tujuan wisata di Sulawesi Selatan, dimana Malino sebagai daerah tujuan wisata alam dan wisata budaya dan sejarah.
\end{abstract}

\section{Kata Kunci : Malino, Kota Perdamaian, Kawasan Wisata}

\begin{abstract}
This study aims to find out the general picture of Malino as a conference and tourist venue that started from 1946 to 2002, and also explained the background of the Malino conference in Tinggimoncong Sub-district. This research uses a historical research method consisting of four stages, namely heuristic (searching and collecting sources), source criticism (internal criticism and ektern), interpretation (source interpretation) and historiography (historical writing). Methods of data collection is done by conducting field research consisting of interviews and collecting archives and related literature. This study is a historical research with qualitative descriptive approach, so that in the process of research using research methods in accordance with historical scientific rules consisting of several stages. The stages are heuristics, criticism, interpretation, and historiography. The results of this study indicate that Malino as a place of conference and tourist attractions, in 1946 was the beginning of Malino serve as the venue for the establishment of NIT conferences by the Dutch colonial, then in the reform era between 2001 and 2002 there are at least two important activities of peace negotiations Poso conflict and the Maluku conflict also held in Malino where the
\end{abstract}


negotiations reached a peace agreement between the conflicting parties. In addition to Malino as a place of peace as well as a tourist area where since 1975 Malino serve as a tourist destination in South Sulawesi, where Malino as a natural tourist destination and cultural and historical tourism.

\section{Keyword: Malino, City of Peace, Tourism Area}

\section{A. Pendahuluan}

Sejarah sebagai salah satu disiplin ilmu, titik kajiannya terletak pada manusia dan segala aktifitasnya. Setiap peristiwa sejarah tidak pernah lepas dari pengaruh manusia, sebagai pelaku dan penyebab terjadinya suatu peristiwa sejarah. Keberadaan manusia sebagai objek dan subjek sejarah tersebut, sehingga dengan diharapkan dengan mempelajari sejarah, akan muncul suatu gagasan, inspirasi, dan dukungan moral dalam mengakumulasikan peristiwa masa lalu secara obyektif, selanjutnya dijadikan patokan dalam melihat masa sekarang dan masa yang akan datang. Hal ini sejalan dengan pendapat yang di kemukakan oleh Roeslan Abdulgani, bahwa :

"Sejarah adalah salah satu bidang ilmu, yang meneliti dan menyelidiki secara sistematis, keseluruhan perkembangan masyarakat serta keanusian di masa lampau beserta kejadian-kejadiannya, dengan maksud kemudian menilai secara kritis seluruh hasil penelitian dan penyelidikan tersebut, untuk akhirnya dijadikan pedoman bagi penelitian dan penentuan keadaan sekarang serta progres masa depan (Abdulgani, 1963)

Malino adalah tempat konferensi atau perundingan sebuah peristiwa besar dalam sejarah, baik pada masa kerajaan maupun era revolusi kemerdekaan, bahkan hingga kini. Selain Malino dikenal sebagai kota perdamaian, juga merupakan salah satu daerah di Sulawesi Selatan yang dikenal sebagai daerah tujuan wisata.
Malino sejak dulu dikenal sebagai tempat wisata, oleh karna tempatnya yang sejuk dan berada di daerah pegunungan, maka keunggulan yang dimiliki oleh Malino dalam hal kekayaan akan jenis objek-objek wisata akan meningkatkan pendapatan masyarakat dan pemerintah, maka dari itu merupakan aset wisata yang perlu di kembangkan dan dipelihara.

Malino telah lama dikenal oleh masyarakat, dimana telah menyelenggarakan berbagai kegiatan nasional seperti perundingan di era reformasi yakni menyelenggarakan perundingan konflik Poso di tahun 2001 dengan perundingan konflik Maluku ditahun 2002. Dan saat itu juga mulailah diperkenalkan Malino sebagai tempat wisata utamanya wisata alam maupun wisata budaya/sejarah.

Malino, yang dikenal daerah yang sejuk ini, akan membawa kesejukan hati bagi para perunding untuk mencari solusi dari sebuah permasalahan. Kalau di tingkat dunia, PBB (Perserikatan Bangsa-Bangsa) sering melakukan konferensi atau perundingan di Swiss, maka di Sulawesi Selatan khususnya di Kabupaten Gowa, Malino juga sering di jadikan tempat konferensi atau perundingan.

Demikian halnya pada penyelesaian konflik etnis di Poso pada tahun 2001 dan Ambon tahun 2002. Kedua permasalahan yang memakan banyak korban bisa terselesaikan lewat perundingan damai di Malino. Perundingan yang di pelopori oleh pemerintah pusat dan tokoh masyarakat Sulawesi Selatan HM Jusuf Kalla, serta dukungan dari pemerintah Sulawesi Selatan dan Pemerintah Kabupaten Gowa, telah 
berhasil mempertemukan kedua belah pihak yang bertikai. Hal ini membuktikan bahwa kondisi politik dan keamanan di kawasan Indonesia timur khususnya di Sulawesi Selatan membaik dalam mendukung perdamaian di Indonesia khusunya konflik etnis Poso \& Ambon.

Adapun pokok permasalahan yang dikaji penulis dalam pembahasan ini hanya mengungkap peranan Malino sebagai tempat penyelenggara konferensi atau perundingan damai tepatnya di tahun 1946 Gubernur Jenderal Van Mook memilih Malino sebagai tempat berlangsungnya pembentukan NIT, serta perundingan damai Konflik Poso dan Maluku di tahun 2001 dan 2002. Selain kajian mengenai peranan Malino sebagai tempat konferensi juga berperan sebagai tempat wisata.

Adapun waktu pembahasan dibatasi di tahun 1946 sebagai awal daridiadakannya konferensi Malino pada saat pembentukan NIT oleh kolonial Belanda, terakhir ditahun 2002 telah diberlangsungkan perundingan konflik Maluku. (Tika \& Syam, 2006)

\section{B. Metode Penelitian}

Penelitian ini menggunakan metode sejarah, menurut Nugroho Notosusanto (1971:17), metode sejarah memiliki tahapan kerja, yaitu: Heuristik, tahap ini merupakan tahap awal dalam penelitian dengan cara mengumpulkan dan menghimpun data sebanyak mungkin yang ada hubungannya dengan obyek yang diteliti. Proses tersebut melalui dua cara yaitu penelitian lapangan yang meliputi dua kegiatan yaitu observasi dan wawancara.

Kritik Sumber atau Penilian Bahan, setelah data terkumpul maka penulis menilai atau mengkritik sumber yang telah diperoleh baik berupa kritik ekstern maupun intern terhadap data yang berhasil dihimpun dalam pengumpulan data. (Hamid \& Madjid, 2011)

Interpretasi atau Penafsiran, setelah diadakan kritik maka diadakan interpretasi atau penafsiran terhadap data sejarah yang diperoleh dalam bentuk penjelasan terhadap fakta seobjektif mungkin. Dalam tahap ini diperlukan ketelitian untuk menghindari interpretasi yang subjektif terhadap fakta, hal ini dimaksudkan untuk mendapatkan kesimpulan suatu peristiwa sejarah yang ilmiah.

Histonografi atau Penulisan Sejarah, tahap ini merupakan tahap akhir dalam metode penulisan sejarah. Dalam tahap ini semua data yang telah terseleksi (fakta) dapat disusun kembali menjadi satu kisah sejarah yang lengkap berdasarkan urutan kejadiannya guna untuk dipaparkan dalam suatu kisah sejarah. (Hamid \& Madjid, 2011)

\section{Tinjauan Penelitian}

Malino merupakan salah satu wilayah di Kabupaten Gowa yang merupakan ibukota dari Kecamatan Tinggimoncong, secara letak wilayah disebelah timur Kabupaten Gowa. Bila dilihat dari kecamata sejarah, Tinggimoncong pada abad Tumanurunga (1320) belum termasuk dalam kerajaan Gowa. Gowa pada masa itu hanya terdiri dari Sembilan Kasuwiang atau lebih populer disebut Kasuwiang Salapanga yang dikoordinir oleh Paccallaya.

Malino yang kita kenal sekarang ini merupakan tempat peristirahatan, sebelum muncul nama Malino, masyarakat setempat mengenalnya dengan kampung 'Lapparak'. Lapparak dalam bahasa Makassar berarti datar, yang berarti pula hanya di tempat itulah yang merupakan daerah datar di puncak pegunungan yang hanya ditumbuhi semak-semak belukar. Secara keseluruhan luas wilayah Kecamatan Tinggimoncong adalah 275,63 Km2. Malino berada disebelah timur kota Sungguminasa, sekitar $61 \mathrm{Km}$ dari Sungguminasa dan $71 \mathrm{~km}$ dari kota Makassar. Secara geografis Malino Kecamatan Tinggimoncong mempunyai batas wilayah sebagai berikut:

a. Sebelah utara berbatasan dengan Kabupaten Bone dan Kabupaten Maros

b. Sebelah timur berbatasan dengan Kabupaten Sinjai dan Kabupaten Bulukumba 
c. Sebelah selatan berbatasan dengan Kecamatan Tompobulu Kabupaten Gowa

d. Sebelah barat berbatasan dengan Kecamatan Parangloe Kabupaten Gowa.

Pada dasarnya penduduk Malino merupakan penduduk heterogen, yang akhirnya menjadi penduduk asli maupun penduduk pribumi. jumlah penduduk penduduk Kecamatan Tinggimoncong mulai tahun 1991-1997 cenderung mengalami peningkatan. Jika dibandingkan jumlah penduduk laki-laki dengan penduduk perempuan, dimana penduduk laki-laki pada tahun 1997 sebanyak 25.701 sedangkan jumlah penduduk perempuan 26.531. Salah satu faktor yang menyebabkan terjadinya peningkatan penduduk adalah kurangnya angka kematian dan kurang diterapkannya program keluarga berencana dalam lingkungan keluarga. (BPS, 1997)

Kecamatan Tinggimoncong yang kaya akan sumber daya alam karena didukung oleh kondisi geografis yang subur, sehingga dapat meningkatkan perekonomian masyarakat khususnya dibidang pertanian dan perkebunan, sehinnga rata-rata penduduk bermata pencaharian disektor tersebut dan sisanya adalah pedagang.

Malino yang kita kenal sekarang ini merupakan tempat peristirahatan, sebelum muncul nama Malino, masyarakat setempat mengenalnya dengan kampung 'Lapparak'. Lapparak dalam bahasa Makassar berarti datar, yang berarti pula hanya di tempat itulah yang merupakan daerah datar di puncak pegunungan yang hanya ditumbuhi semak-semak belukar, "Lapparak juga dikenal oleh masyarakat sebagai tempat perumputan hewan". Lebih lanjut M Arsyad Menjelaskan sebagai berikut:

"Apabila kita melewati jalan yang akan menuju Malino, maka terdapat sebuah sungai Malino yang dihubungkan dengan jembatan gantung lebong. Sungai Malino airnya amat tenang yang dapat memberikan ketenangan dan kesejukan dihati. Sesuai dengan
Namanya Malino yang artinya amat tenang. Ketika akan memasuki wilayah Malino maka akan nampaklah sebuah tembok prasasti di pinggir jalan dengan nama tulisan Malino 1927.” (Arsyad, 2018)

Malino baru dikenal dan semakin populer sejak zaman penjajahan Belanda, lebih-lebih setelah Gubernur Caron pada tahun 1927 memerintah di "Celebes on Onderhorighodon” telah menjadikan Malino sebagai tempat peristirahatan bagi para pegawai pemerintah dan siapa saja dari pemerintah warga Kota Makassar (Ujung Pandang) sanggup dan suka membangun bungalow atau villa ditempat sejuk ini. (Hasbullah, 2013)

\section{Pembahasan}

\section{Malino Sebagai Tempat Konferensi}

a. Konferensi Malino Pembentukan NIT 1946

Konferensi Malino dicanangkan untuk membicarakan gagasan "Politik Federal" antara pihak Belanda dengan tokoh-tokoh masyarakat yang cenderung pada ide bentuk Negara Federal yang dipromosikan Pemerintah Belanda. Usaha ini sebenarnya bertujuan untuk memecah belah wilayah Indonesia dalam bentuk Pemerintahan Federal (Negara-negara bagian) yang terikat dengan Kerajaan Belanda dan Republik Indonesia akan dijadikan sebagai salah satu negara bagian.

Khusus Indonesia, Belanda sudah sejak April 1944 telah mempersiapkan pendudukan kembali atas negara Indonesia. Dimana antara Belanda dan Inggris telah menyelenggarakan perundingan-perundingan di London dan Kandy, dimana perundingan tersebut menghasilkan "Civil Affairs Agreement" yang isinya antara lain ; Pengaturan penyerahan kembali Indonesia dari pihak Inggris kepada pihak Belanda khusus yang menyangkut Sumatera (Daerah Indonesia yang dibawahkan oleh South East Asia Command, SEAC). (Nurjayanti, 2007)

Disaat itu, Belanda ingin menerapkan politik adu domba (Devide et Impera) 
dengan cara membuat negara Indonesia menjadi beberapa negara bagian. Khusus diwilayah Timur Nusantara, Belanda bermaksud untuk satu Negara bagian yakni Negara Indonesia Timur (NIT). Dibagian barat Indonesia, sudah dibentuk beberapa Negara bagian, seperti Negara Pasundan, Negara Jawa Timur, Negara Madura, Negara Sumatera Utara, Sumatera Selatan, Kalimantan Barat, Kalimantan Timur. Namun setelah dekrit Presiden Juli 1959, maka negara bentukan Belanda ini bubar dan kembali kepangkuan Negara Kesatuan Republik Indonesia. (Nurjayanti, 2007)

Sebelum Konferensi diadakan, Belanda telah menyiapkan kooperatorkooperator yang akan dijadikan sebagai wakil dari berbagai daerah untuk menghadiri Konferensi tersebut. Belanda hanya memilih orang-orang yang memenuhi syarat-syarat yang telah ditentukan oleh Belanda sendiri. Alasan Van Mook memilih Malino sebagai tempat berlangsungnya Konferensi yakni kedudukan Sulawesi Selatan yang sangat strategis dari sudut politis, ekonomis, dan geografis. Disamping itu Van Mook juga ingin memperlihatkan kepada umum bahwa pemerintah Belanda telah menguasai politik dan keamanan di Sulawesi Selatan

Sehari sebelum konferensi berlangsung, yakni pada tanggal 15 Juli 1946, semua peserta sudah hadir. Mereka masing-masing diberi penginapan dibeberapa tempat yang tersebar di Malino sedangkan ruang rapat tempat konferensi akan diadakan telah dipersiapkan pula di sebuah Gereja Katolik milik Misa. Van Mook sendiri telah tiba di Malino pada saat pelaksanaan konferensi berlangsung. Para peserta yang menghadiri Konferensi Malino terdiri dari perwakilan dari pihak Belanda, dan pihak Indonesia yang terdiri dari pemuka rakyat, aliran-aliran masyarakat, kepala-kepala swapraja dan himpunan masyarakat adat serta tidak ketinggalan anggota pers baik dari dalam maupun luar negeri untuk meliput jalannya konferensi. Setelah semua peserta hadir didalam ruang rapat, konferensi Malino segera dibuka oleh Vaan Mook. Dimana rencananya konferensi dilaksanakan selama sepuluh hari dari tanggal 16 Juli-25 Juli 1946.

Konferensi Malino pada umumnya membahas tentang rencana pembentukan Negara-negara Federal sebagai bagian dari suatu Negera Federal dan susunan ketatanegaraan bentuk negara federal. Dimana dalam konferensi berlangsung, muncul berbagai resolusi, mosi serta pertanyaandari peserta. Namun perdebatan yang paling serius adalah mengenai bentuk negara.

Muncul perdebatan yang dilatar belakangi oleh adanya dua golongan yang menghendaki bentuk negara federal dan ada yang menginginkan bentuk kesatuan. Bagi golongan yang menginginkan bentuk federal melihat bahwa bangsa Indonesia terdiri dari beberapa kelompok etnis kultural yang mempunyai ciri budaya masing-masing serta perbedaan sifat-sifat ekonomi antara pulau Jawa dan diluar pulau Jawa.

Sedangkan bagi golongan yang menginginkan bentuk negara kesatuan berpandangan bahwa Indonesia adalah negara bekas jajahan Belanda, dengan mempunyai perasaan historis yang sama, karena secara politis kesatuan itu lebih ditentukan oleh situasi historis tertentu. Terlepas dari perdebatan itu, konsep Negara Federal tetap menjadi dasar diadakannya konferensi ini.

Secara garis besarnya konferensi ini memutuskan tentang wakil-wakil rakyat untuk mewujudkan perombakan struktur dan politik Nederland Indies menjadi negara merdeka dan berdaulat. Negara Indonesia Serikat yang terdiri dari empat negara bagian yaitu ; Jawa, Sumatera, Kalimantan dan Timur (Grote Dost). Serta konferensi ini memutuskan peralihan pemerintahan dari pihak Belanda ke Pemerintahan Negara Indonesia Timur.

Akhirnya setelah seluruh rangkaian kegiatan telah dilangsungkan selama beberapa hari dan telah menghasilkan keputusan, maka tepat pukul 17:00 Wita 
pada tanggal 25 Juli 1946 konferensi tersebut ditutup oleh Van Mook

\section{b. Perundingan Konflik Poso 2001}

Salah satu peristiwa yang meluluhlantahkan bangunan integrasi nasional Indonesia adalah terjadinya konflik bernuansa SARA di Poso pada tahun 1999. Konflik tersebut semakin meluas karena adanya kondisi masyarakat Poso yang terbagi menurut garis etnik dan agama. Pengelompokan masyarakat berdasarkan perbedaan etnik dan agama tersebut menyebabkan daerah Poso sangat rawan terhadap timbulnya konflik sektarian bernuansa SARA. Timbulnya konflik Poso bermula dengan terjadinya penyerangan sekelompok pemuda pada bulan desember 1998. (Koto, 2012)

Konflik Poso yang telah terjadi sejak 1998 telah mengakibatkan jatuhnya korban yang tidak sedikit. Dalam peristiwa memilukan ini, terdapat indikasi kuat adanya campur tangan dari para elite politik dan motif "pembiaran" atas berbagai tindakan kriminal yang terjadi tanpa adanya penyelesaian secara hukum. Akibatnya, sebagaimana kita lihat, konflik malah semakin meluas kelima kecamatan di Kabupaten Poso serta Kabupaten Morowali. Konflik kemudian dikondisikan dan dipersepsikan seolah-olah itu merupakan konflik horizontal antara komunitas muslim dan Kristen. (Hasrullah, 2009)

Konflik poso berawal ditahun 1998 hingga 2001, merupakan konflik ethnocommunal banyak dipicu oleh pertikaian antar pemuda ketimbang sentiment agama murni. Konflik Poso pada awalnya sangat terkait dengan kompetisi elite lokal. Mengatasi konflik di Poso yang berkepanjangan, maka pemerintah berinisiatif untuk mendamaikan kelompok yang bertikai yakni pihak islam dan pihak Kristen atau Deklarasi Malino I untuk Poso, adalah sebuah perjanjian damai yang dilaksanakan oleh Pemerintah Indonesia pada tanggal 20 Desember 2001 di Malino yang bertempat di Hotel Celebes. Perjanjian ini mempertemukan pihak
Kristen dan Islam yang bertikai di Poso dalam konflik komunal sepanjang tahun 2000 hingga 2001. Pertemuan ini dipimpin oleh Menteri Koordinator Bidang Kesejahteraan Rakyat Republik Indonesia pada saat itu, Jusuf Kalla. (Hasrullah, 2009). Menyetujui poin-poin persetujuan di Deklarasi Malino, dua komisi kemudian dibentuk: Komisi Keamanan dan Penegakan Hukum, serta Komisi SosioEkonomi. Komisi Keamanan memiliki dua tanggung jawab utama: Yang pertama, dalam bidang keamanan harus difokuskan kepada pelucutan senjata dan pemulangan para pengungsi; yang kedua, dalam bidang Penegakan Hukum.

Komisi Sosio-Ekonomi memiliki 10 poin program: upaya rekonsiliasi, rehabilitasi sosial, pemulangan pengungsi, asuransi keyakinan hidup, rehabilitasi fisik, normalisasi aktivitas ekonomi warga, dukungan sosial, mengembangkan program induk, evaluasi dan pemantauan reguler, dan pegembangan program yang berkaitan dengan hal ini. Program ini di atur oleh Departemen Urusan sosial (Dinas Urusan Sosial Poso), dengan pengecualian bahwa dana rekonsiliasi dikontrol oleh Pemerintah Daerah Poso dan Kelompok Kerja Malino 1. (Wikipedia, 2001)

Perundingan konflik Poso dalam Perundingan Malino I mejadi sejarah tersendiri bagi pemerintah daerah Sulawesi Selatan maupun pemerintah Kabupaten Gowa dan terkhusus kepada tingkat kecamatan sebab Malino dijadikan sebagai tempat perundingan damai dalam konflik Poso yang telah terjadi dari tahun 1998 hingga tahun 2001. Malino adalah tempat yang netral, sebab jauh dari tempat konflik berlangsung.

Perundingan damai Malino I berlangsung dengan aman dan lancar Dari hasil itu dalam sebuah kesepakatan yang dilaksanakan di Hotel Celebes Malino yang beralamat di Jalan Sultan Hasanuddin yang berlangsung antara 19-20 Desember 2001 maka menghasilkan suatu Deklarasi dalam penyelesaian konflik Poso. Mulai saat itu Malino dikenal sebagai kota perdamaian 
yang telah sukses menggelar suatu kegiatan yang bersifat nasional yakni melaksanakan perundingan konflik Poso.

\section{c. Perundingan Konflik Maluku 2002}

Dinamika sejarah di Indonesia, posisi dan peran Maluku mengalami pasang surut. Pada periode kolonialisme bangsa-bangsa Barat, Maluku menjadi salah satu wilayah nusantara yang paling gigih melancarkan perlawanan terhadap kaum penjajah.Keberhasilan Sultan Baabullah dari Ternate dalam mengusir Portugis dari Maluku, merupakan salah satu torehan sejarah kemenangan yang monumental dari kaum pribumi terhadap hegemoni imperial Barat. Sementara itu perang Maluku yang dipimpin oleh Thomas Matulessy atau yang dikenal Pattimura, dicatat oleh sejarah sebagai salah satu perlawanan yang paling heroik dalam menentang ekploitasi Belanda di Bumi rempah-rempah. (Koto, 2012)

Pada masa revolusi pasca proklamasi. Maluku berkembang menjadi salah satu kawasan yang cukup dinamis. Masyarakat Maluku dikenal sebagai masyarakat majemuk yang dicirikan dengan heterogenitas etnik dan agama dari penduduk yang mendiaminya. Kepulauan Maluku tidak hanya didiami oleh penduduk asli Maluku, namun juga mencakup penduduk pendatang dari berbagai Kawasan Indonesia, terutama Bugis, Buton, Makassar, Minahasa, Jawa dan Cina. Dari segi komposisi pemeluk agama, Islam dan Kristen Protestan merupakan dua agama yang dipeluk oleh sebagian besar rakyat Maluku dalam proporsi yang cukup seimbang. (Buntu, 2018)

Sejak pertama kali berkobar pada tanggal 19 Januari 1999, konflik di Maluku baru dianggap relatif terhenti empat tahun kemudian, yaitu pada tanggal 15 September 2003, bersamaan dengan ditetapkannya Maluku sebagai daerah tertip sipil. Akibat paling nyata dari konflik Maluku adalah jatuhnya korban jiwa, pengungsi, kerusakan infrastruktur fisik, serta lumpuhnya kehidupan ekonomi dan sosial.
Konflik di Maluku merupakan salah satu konflik yang tingkat eskalasinya sangat massif dan berlangsung dalam kurun waktu yang lama. Secara umum, peta konflik di Ambon dapat dibagi menjadi tiga tahap, yaitu tahap pra-konflik, ekskalasi konflik, dan post-conflik.

Pada tanggal 12 Februari 2002, momentum penting untuk perdamaian di Maluku terjadi ketika pihak-pihak yang bertikai berhasil menyepakati dan menandatangani Deklarasi Malino II di Malino, Kabupaten Gowa. Deklarasi tersebut merupakan hasil dari dialog panjang antara tokoh-tokoh agama dan adat Maluku dan kemudian dipertemukan kedua pihak yang bertikai yang dimediasi oleh pemerintah pusat melalui Menko Kesra Jusuf Kalla. Kesepakatan yang memikat tiga pihak, yaitu pihak Kristen, Islam, dan pemerintah pusat.

Belajar dari perundingan Malino I dalam penyelesaian konflik Poso, Malino kembali dipercaya sebagai tempat penyelenggara kasus penyelesaian konflik Maluku yang kasusnya sama dengan kasus Poso. Perundingan antara dua kelompok yang selama ini bertikai di Maluku, yang di gelar sama tempatnya di Hotel Celebes pada 11-12 februari 2002. Kepastian jadwal kedua kelompok, Islam dan Kristen bertemu secara terpisah dengan tim mediator pemerintah di Makassar. Semula rencana perundingan dilaksanakan pada 57 Februari. (Koto, 2012)

Sebanyak 70 delegasi kelompok Islam dan Kristen yang selama lebih tiga tahun bertikai di Maluku yang hadir dalam perundingan Malino II sepakat menghentikan konflik, yang difasilitasi oleh pemerintah dalam hal ini yang menjadi pencetus adalah Menko Kesra Bapak Jusuf Kalla.

Perundingan Malino II dalam penyelesaian konflik Maluku mencerminkan keberlangsungan proses penyelesaian politik antara pihak-pihak yang bertikai di Maluku sekaligus juga langkah awal bagi pendekatan problemsolving. Hasil perundingan Malino II 
disambut dengan sangat antusias dan penuh harapan oleh rakyat Maluku. Derita yang terperikan akibat konflik telah membuat rakyat jera dan mendambakan perdamaian yang sejati. Secara perlahan perjanjian damai tersebut berhasil menciptakan situasi yang kondusif bagi interaksi damai masyarakat Maluku. (Koto, 2012)

\section{Malino Sebagai Tempat Wisata}

a. Malino Sebagai Daerah Tujuan Wisata

Pariwisata merupakan salah satu upaya menghilangkan rasa jenuh ataudengan kata lain berwisata merupakan proses bepergian sementara untuk mencari kesenangan atau kebahagian serta untuk mengetahui tempat yang dikunjungi.Dalam perkembangannya sejak tahun 1975 Malino ditetapkan sebagai 6 daerah tujuan wisata di Sulawesi Selatan. (Pendit, 1994)

Malino memiliki panorama yang indah juga lebih dikenal tempat yang hawanya sejuk dan dingin. Malino juga terkenal dengan dengan tanahnya yang subur dan menghasilkan buah-buahan, seperti markisa, alvukat, serta sayur.

Sesuai dengan kondisi dan keindahan alam yang terdapat di Malino diarahkan pada wisata alam, wisata budaya atau wisata sejarah. Salah satu yang menonjol dari keindahan alam Malino adalah adanya hutan pinus dan air terjun yakni air terjun Takapala, air terjun Ketemu Jodoh, dan lain sebagainya. Selain itu juga terdapat obyek wisata sejarahdan budaya yakni Balla Lompoa dan Gedung bekas Konferensi Malino yang merupakan salah satu peninggalan sejarah yang dapat memberikan gambaran tentang peristiwa masa lampau terhadap generasi sekarang dan masa akan datang, dalam memperkuat kepribadian dan untuk mempertebal semangat kebangsaan.

Selain itu, untuk menjadikan Malino sebagai daerah tujuan wisata tidaklah terlepas dari perlunya sarana dan prasarana yang memadai. Hal itu tidak terlepas dari adanya keterlibatan pihak pemerintah maupun pihak swasta serta masyarakat.

Perkembangan selanjutnya, yakni berdasarkan riset secara menyeluruh yang dilaksanakan oleh Prof. Kushardinoto yang menjabat sebagai Biro Kunsultan Pariwisata dari PT. Indah Cipta yang dipercayakan oleh pemerintah untuk melakukan riset sekaligus menyusun Rencana Induk Pengembangan Pariwisata (RIP) Sulawesi Selatan pada tahun 1975-1977. Hasil tersebut ditetapkanlah enam Daerah Tujuan Wisata (DTW) Sulawesi Selatan dengan Malino sebagai salah kawasan wisata yang dimaksud.

\section{b. Wisata Alam \\ 1) Hutan Wisata}

Hutan wisata atau yang dikenal dengan sebutan Hutan Pinus yang terdiri dari deretan pohon pinus yang tumbuh subur, kokoh dan rindang. Hutan wisata Malino, walaupun belum terkenal diluar daerah Sulawesi selatan namun Malino sangat potensial menjadi Kawasan wisata unggulan di Indonesia. Kalau Bandung terkenal dengan julukan "Kota Kembang", maka Malino disebut sebagai "Kota Bunga di Sulawesi Selatan”. Julukan ini muncul karena banyak spesies bunga yang muncul disekitran hutan wisata. Hasil penelitian Gerard Van Went (2007) dari Lembaga penelitian Belanda pada program "Programme Uitzending Managers" menyatakan bahwa sekitar $60 \%$ bunga yang tumbuh dikawasan Hutan wisata diantaranya bunga anggrek dan edelweiss yang banyak dijajakan oleh para pedagang.

Dipinggir Malino, dijalan Pendidikan diantara deretan pepohonan pinus Taman Wisata Alam Malino, terbuka areal seluas satu hektar. Diareal ini biasa digunakan oleh Parabus Malino Adventure Tour and Outbond untuk menyelenggarakan kegiatan Outbond. Umumnya pesertanya berasal dari kalangan karyawan perusahaan dalam rangka membangun semangat kerja atau pun kepemimpinan yang dikemas dalam bentuk permainan tematik dan menantang. Dan terbuka pula untuk kalangan lainnya dengan sistem pemesanan dalam rombongan wisata.

\section{2) Air Terjun Takapala}

Kondisi daerah pegunungan

Bawakaraeng yang terdiri dari gunung dan 
jurang disertai sumber air yang berasal dari pegunungan, telah banyak membentuk air terjun diberbagai lokasi, salah satunya adalah air terjun Takapala yang terletak di Kelurahan Buluttana. (Huho, 2018)

Air yang mengalir di Air terjun Takapala itulah yang mengalir ke sungai jeneberang yang kemudian banyak memberikan kehidupan bagi masyarakat didaerah dataran rendah, yakni sebagian airnya digunakan untuk mengairi persawahan, pembangkit tenaga listrik, dan sumber air minum bagi warga kota Makassar dan sekitarnya. Kini air terjun Takapala merupakan salah satu obyek wisata alam di Malino, setiap hari-hari libur banyak dikunjungi oleh wisatawan. Disekitar itu pula banyak para pedagang kakilima serta warung sederhana dan tempat istirahat yang dibangun oleh masyarakat sekitar. Menurut informasi dari warga bahwa air terjun Takapala menyimpang banyak misteri yang berbau megic.Biasanya air terjun menghadap kebarat dan airnya langsung mengalir kebarat mengikuti alur sungai Jeneberang, namun bagi air terjun satu ini posisinya menghadap ketimur tempat matahari terbenam, tapi airnya mengalir kebarat sampai kehulu sungai. Dari sekian banyak di Malino, air terjun Takapala ini juga memiliki keanehan. Biasanya air terjun menghadap kebarat dan airnya langsung mengalir kebarat mengikuti alur sungai Jeneberang, namun bagi air terjun satu ini posisinya menghadap ketimur tempat matahari terbenam, tapi airnya mengalir kebarat sampai kehulu sungai.

\section{3) Air Terjun Ketemu Jodoh}

Air terjun ini bertetangga dengan air terjun Takapala yang jaraknya hanya $1 \mathrm{Km}$, posisi air terjun Ketemu Jodoh letaknya 300 meter dari poros jaln. Untuk sampai kelokasi harus melalui jalan setapak yang sudah dibeton sehingga memudahkan pengunjung masuk kelokasi itu. Banyak masyarakat utamanya muda-mudi percaya, bila mandi di air terjun itu dapat berjodoh hinggah kepelaminan. Air terjun Ketemu Jodoh ini satu dari dua obyek wisata air terjun yang dibawa pengawasan Dinas Pariwisata Kabupaten Gowa. Sumber air terjun ini berasal dari tiga sungai yakni sungai balino parang, biroro, dan sungai parang leppa. Ketiga sungai itu kemudian bertemu di air terjun ketemu jodoh dan selanjutnya mengalir kealur sungai jeneberang. (Huho, 2018)

Pada sisi dinding gunung itu terdapat liang yang dibawahya terdapat dua titik yang dialiri air. Pada dua titik itulah yang disebut ketemu jodoh. Bila ada pasangan muda mudi sebelum turun mandi mereka terlebih dahulu kedua titik tersebut untuk membasuh muka sambal berdoa agar ia dijodohkan dengan kekasihnya sampai kepelaminan untuk membentuk keluarga, setalah itu, barulah mereka turun mandi untuk membersihkan sial yang melekat pada dirinya. Terbukti, memang banyak muda mudi yang pernah datang ke air terjun ini kemudian kembali memenuhi janjinya setelah mereka melangsungkan pernikahan. Mereka melakukan pesta kecilkecilan sambal rekreasi ditempat ini, ada yang memotong kambing, ayam sebagai tanda, bahwa apa yang dicita-citakan telah terwujud. (Hasriani, 2018)

\section{c. Wisata Sejarah}

\section{a) Balla Jambu dan Balla Lompoa}

Kawasan adat Bulutana, sebuah kawasan seluas 2 ha yang disebut sebagai Butta Toa, pusat pemerintahan adat Bulutana di masa lalu.Butta Toa sendiri saat ini secara administratif berada di Kelurahan Bulutana. Terdapat sekitar 20an kepala keluarga yang berdomisili di tempat ini.Kelurahan Bulutana, sebagai daerah utama kawasan adat Bulutana, berada di Kecamatan Tinggimoncong, dengan luas wilayah mencapai 21,5 km2. Sebagian besar menggantungkan hidupnya dari sektor pertanian, khususnya padi, kopi dan cengkeh, serta beternak sapi.

Perjalanan menuju Butta Toa selalu menjadi pengalaman yang menyenangkan dan sekaligus mendebarkan. Bukan hal yang mudah. Jalanan yang berkelok dengan lembah di sekeling, disertai kondisi jalan 
yang masih dalam upaya pengerasan batu cadas, menjadi tantangan tersendiri.

Sekitar 20 menit berkendara dari jalan poros desa maka tibalah di pintu gerbang Butta Toa. Ada keheningan yang terasa ketika memasuki kawasan ini.Jalanan berbatu hasil pengerasan beberapa tahun sebelumnya membuat kawasan ini terlihat rapidan bersih, dengan deretan Bunga Siri' berwarna ungu berjejeran di sepanjang jalan. Rumah-rumah, yang sebagian besar adalah rumah panggung, berjejer mengelilingi sebuah tanah lapang kecil.Di kawasan Butta Toa ini juga terdapat rumah kediaman Karaeng Bulu, pemimpin tertinggi, yang disebut Balla Jambu.

Struktur bangunannya nyaris sama dengan Balla Lompoa dengan tiang utama yang juga diukiri motif dan aksara Toraja. Bangunan ini pun masih terlihat kokoh meski umurnya sudah ratusan tahun.

Dikawasan ini terdapat dua bangunan bersejarah yakni Balla Lompoa dan Balla Jambu. Rumah adat Balla Jambu juga berfungsi sebagai tempat untuk acara-acara adat lainnya seperti syukuran atas panen yang melimpah dan lain-lain. dengan diperkenalkannya Balla Jambu sebagai Kawasan wisata budaya/sejarah di Malino, dapat menarik minat wisata lokal maupun mancanegara untuk mengunjungi kawasan ini. (Sikki, 2018).

\section{E. Kesimpulan}

Malino adalah tempat konferensi atau perundingan sebuah peristiwa besar dalam sejarah, baik pada masa kerajaan maupun era revolusi kemerdekaan, bahkan hingga kini. Selain Malino dikenal sebagai kota perdamaian, juga merupakan salah satu daerah di Sulawesi Selatan yang dikenal sebagai daerah tujuan wisata. Itu dibuktikan dengan dilaksanakannya konferensi Malino pembentukan NIT (Negara Indonesia Timur) pada masa kolonial Belanda. Serta era reformasi ditahun 2001 dan tahun 2002 melaksanakan kegiatan besar yakni perundingan damai Malino I terkait dengan konflik Poso serta perundingan damai Malino II terkait dengan konflik Maluku.
Malino yang menjadi kota terbesar kedua di Kabupaten Gowa setelah Sungguminasa, ini menyimpang banyak kenangan karna berperan besar dalam berbagai peristiwa sejarah yang tak pernah terlupakan, dimana sejarah itu akan dikenang sepanjang hayat, dimana kita kenal Malino berperan dalam pembentukan NIT oleh kolonial Belanda pada tahun 1946 dimana pada umumnya konferensi tersebut membahas pembentukan negara-negara federal, dimana konferensi tersebut dilatar belakangi oleh adanya dua golongan yang menghendaki bentuk negara federal dan ada yang menginginkan bentuk kesatuan. Bagi golongan yang menginginkan bentuk federal melihat bahwa bangsa Indonesia terdiri dari beberapa kelompok etnis kultural yang mempunyai ciri budaya masing-masing serta perbedaan sifat-sifat ekonomi antara pulau Jawa dan diluar pulau Jawa.

Sedangkan bagi golongan yang menginginkan bentuk negara kesatuan berpandangan bahwa Indonesia adalah negara bekas jajahan Belanda, dengan mempunyai perasaan historis yang sama, karena secara politis kesatuan itu lebih ditentukan oleh situasi historis tertentu. Terlepas dari perdebatan itu, konsep Negara Federal tetap menjadi dasar diadakannya konferensi ini. Akhirnya setelah seluruh rangkaian kegiatan telah dilangsungkan selama beberapa hari dan telah menghasilkan keputusan, maka tepat pukul 17:00 Wita pada tanggal 25 Juli 1946 konferensi tersebut ditutup oleh Van Mook. Dimana sebelum menutup Van Mook menyatakan kata perpisahan yang cukup mengharukan, dimana Van Mook mengatakan bahwa "Kita semua selama konferensi Malino ini meletakkan dasar diatas bangunan Indonesia baru dan merdeka akan diwujudkan.

Dimasa reformasi ditahun 2001 dengan 2002 Malino kembali ditunjuk menjadi penyelenggara penyelesaian konflik Poso ditanggal 19-20 Desember 2001, dan Maluku ditanggal 5-7 Februari 
2002, yang memakan banyak korban jiwa, dan pemilihan Malino sebagai tempat penyelenggara tentunya menjadi alasan tersendiri bagi pemerintah. Yang memang Malino adalah tempat yang sejuk dan berada didaerah pegunungan yang jauh dari perkotaan dan kebisingan.

Disamping Malino sebagai penyelenggara konferensi atau perundingan berbagai permasalahan juga tempat kawasan wisata alam dan wisata sejarah/budaya. Di Malino terdapat berbagai obyek wisata alam meliputi panorama air terjun, yang terkenal yakni air terjun takapala dan air terjun ketemu jodoh, serta kaya akan wisata sejarah/budaya seperti balla lompoa dan balla jambu.

\section{DAFTAR PUSTAKA}

Abdulgani, R., 1963. Penggunaan Ilmu Sejarah. Bandung: Prapanntja.

Arsyad, M., 2018. Wawancara di Malino [Interview] (23 Maret 2018).

BPS, 1997. BPS Gowa. Sungguminasa: BPS Gowa.

Buntu, B., 2018. Wawancara di Malino [Interview] (27 Maret 2018).

Hamid, A. R. \& Madjid, M. S., 2011. Pengantar Imu Sejarah. Makassar: Ombak.

Hasbullah, 2013. Sejarah Tinggimoncong. Makassar: Rahman Hasanuddin.

Hasriani, 2018. Wawancara di Malino [Interview] (15 Maret 2018).

Hasrullah, 2009. Dendam Konflik Poso. Jakarta: Gramedia.

Huho, 2018. Wawancara di Buluttana [Interview] (15 Maret 2018).

Koto, I., 2012. Tragedi-tragedi Kemanusian di Indonesia. Yogyakarta: Laksana.

Nurjayanti, 2007. Konferensi Malino 1946, Makassar: Seminar Mata Kuliah.

Pendit, N., 1994. Ilmu Pariwisata Sebuah Pengantar. Jakarta: Pradnya Paramita. Sikki, 2018. Wawancara di Malino [Interview] (30 Maret 2018).
Tika, Z. \& Syam, M. R., 2006. Malino Berdarah. Makassar: Pustaka Refleksi.

Wikipedia, 2001. Deklarasi_Malino. [Online] Available at: http://id.wikipedia.org/wiki

[Accessed 5 April 2018]. 